Мартинович Д. $\mathbf{C}$.

Київський національний університет імені Тараса Шевченка

\title{
АНАЛІЗ ВИБОРУ СТРАТЕГІЧНИХ ВИДІВ ЕКОНОМІЧНОЇ ДІЯЛЬНОСТІ НАЦІОНАЛЬНОЇ ЕКОНОМІКИ ДЛЯ НАДАННЯ ДЕРЖАВНОї ДОПОМОГИ
}

\author{
АНАЛИЗ ВЫБОРА СТРАТЕГИЧЕСКИХ ВИДОВ ЭКОНОМИЧЕСКОЙ \\ ДЕЯТЕЛЬНОСТИ НАЦИОНАЛЬНОЙ ЭКОНОМИКИ ДЛЯ ПРЕДОСТАВЛЕНИЯ \\ ГОСУДАРСТВЕННОЙ ПОМОЩИ
}

\section{ANALYSIS OF STRATEGIC ECONOMIC ACTIVITIES OF NATIONAL ECONOMY FOR ALLOCATION OF STATE AID}

\begin{abstract}
Статтю присвячено визначенню пріоритетних секторів національної економіки за допомогою якісного та кількісного аналізу, використовуючи критерії соціальноекономічного ефекту та впливу на економічну безпеку країни. Підкреслено необхідність оновлення методики розрахунку рівня економічної безпеки України, яка в сучасних умовах не є релевантною. Визначено, щзо видатки державного бюджету мають бути спрямовані на стратегічні сектори національної економіки, які забезпечать енергетичну, інвестиційно-інноваційну, продовольчу, складові безпеки краӥни. Представлено динаміку та розподіл основних показників сочіально-економічного розвитку за видами економічної діяльності. Експертним иляхом обрано основні критерії при виборі стратегічних видів діяльності. Для кожного з критеріїв експертним методом визначено вагові коефіиієнти та розраховано очікуваний ефект від кожної галузі. Визначено, щзо сільське господарство та паливно-енергетичний комплекс $\epsilon$ пріоритетними серед стратегічних видів економічної діяльності для надання державної допомоги.
\end{abstract}

Ключові слова: державна допомога, види економічної діяльності, національна економіка, бюджет, видатки.

Статья посвящена определению приоритетных секторов национальной экономики с помощью качественного и количественного анализа, используя критерии сочиальноэкономического эффекта и влияния на экономическую безопасность страны. Подчеркнута необходимость обновления методики расчета уровня экономической безопасности Украины, которая в современных условиях не является релевантной. Определено, что расходы государственного бюджета должны быть направлены на стратегические секторы национальной экономики, которые обеспечат энергетическую, инвестиционноинновационную, продовольственную составляющие безопасности страны. Представлена динамика и распределение основных показателей сочиально-экономического развития по видам экономической деятельности. Экспертным путем избраны основные критерии при выборе стратегических видов деятельности. Для каждого из критериев экспертным методом определены весовые коэффициенты и рассчитан ожидаемый эффект от каждой отрасли. Определено, что сельское хозяйство и топливно-энергетический комплекс являются стратегическими видами экономической деятельности для предоставления государственной помощи. 
Ключевые слова: государственная помощь, виды экономической деятельности, национальная экономика, бюджет, расходы.

The paper is devoted to definition of priority economic sectors in Ukraine using qualitative and quantitative analysis based on the criteria of social and economic benefits and impact on the economic security of the country. The study emphasizes the need to update the methodology of economic security calculation in Ukraine, which is not relevant in modern conditions. The research determines that the state budget expenditures should be directed to strategic sectors of the national economy, which provide energy, investment and innovation, food, security components of economic security. The paper presents dynamics and distribution of basic indicators of socio-economic development of economic activities. The main criteria for selection of strategic economic activities are chosen using expert method. The research presents the weights for each of the criteria, which defined by the expert method, and expected effects, which calculated of each industry. Agricultural and fuel and energy complex are determined to be among the strategic priorities of economic activities for state aid.

Key words: state aid, economic activities, national economy, budget, expenditures.

Вступ. В умовах затяжної економічної рецесії, політичної невизначеності та жорсткої економії бюджетних коштів в Україні важливо створити прозору та ефективну систему державної допомоги стратегічним видам економічної діяльності національної економіки. Уряд має застосувати на практиці інструменти державної допомоги, які матимуть позитивний ефект та уникати невиправданих витрат, що лише шкодять ринковій конкуренції та викривлюють фіскальний простір. Відповідно, постає питання про вибір економічної діяльності, яка буде отримувати державну допомогу.

Дослідженням теми державної допомоги в Україні активно займалися вчені Г. Гендлер [1], Т. Сфименко [2], Т. Затонацька [3], Д. Серебрянський [4], А. Скрипник [4, А. Соколовська [5] та інші, в працях яких розкривається суть окремих складових державної підтримки, їх кількісні та якісні характеристики. Разом з тим, в останні роки наша держава зазнала великих змін в економічному та геополітичному планах, що робить актуальнім дослідження видів економічної діяльності для надання державної допомоги у нових умовах.

Постановка завдання. Мета написання статті полягає у визначенні стратегічних секторів економіки для надання державної допомоги в умовах дефіциту державних фінансів.

Методологія. У статті представлено кількісні та якісні методи аналізу стратегічних видів економічної діяльності в Україні.

Результати дослідження.

Роль складових економічної безпеки України при виборі стратегічних видів економічної діяльності для надання державної допомоги. Під час планування та імплементації державної політики необхідно враховувати іiі вплив на показник економічної безпеки країни. Відповідно до Наказу «Методичні рекомендації щодо розрахунку рівня економічної безпеки 
України» від 29.10.2013 № 1277, економічна безпека країни - це стан національної економіки, який дає змогу зберігати стійкість до внутрішніх та зовнішніх загроз, забезпечувати високу конкурентоспроможність у світовому економічному середовищі і характеризує здатність національної економіки до сталого і збалансованого зростання. [6]

Економічна безпека сприяє розвитку національної економіки, формує економічну незалежність та забезпечує стабільність у довгостроковому періоді. Обрана політика державної допомоги стратегічним видам економічної діяльності повинна мати на меті структурну перебудову економіки, стимулювання інноваційної діяльності, розвитку малого та середнього бізнесу тощо.

Відповідно до рис.1, який відображає планові видатки державного бюджету України на види економічної діяльності у 2015 році, найбільша частка витрат припадає на транспорт $(58,15 \%)$, 3 яких 99,3\% припадає на дорожнє господарство; друга за величиною частка припадає на сільське господарство, лісове господарство та мисливство, рибне господарство $(10,46 \%)$; третя за величиною частка - паливно-енергетичний комплекс (ПЕК) $(9,20 \%)$. Варто зазначити, що левова частка видатків на транспорт припадає не на розвиток галузі, а на виплату кредитів.

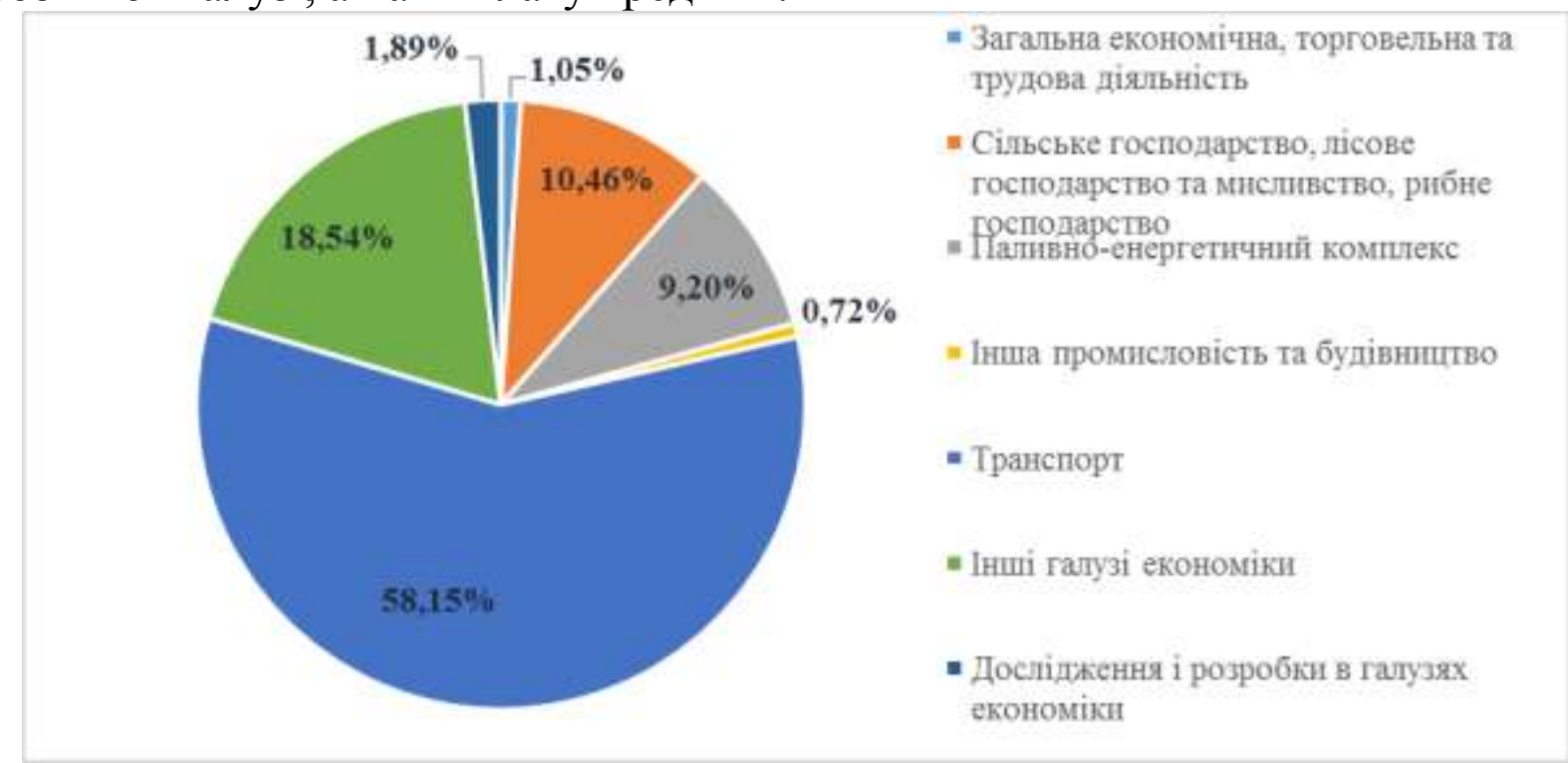

Рис. 1. Планові видатки Державного бюджету України за функціональною класифікацією видатків та кредитування бюджету у 2015 році.

Джерело: побудовано автором на основі [7]

Рис. 1 відображає динаміку видатків державного бюджету України на види економічної діяльності у динаміці 2010-2015 pp. Приходимо до висновку, що протягом останніх шести років найбільша частка видатків 
державного бюджету призначалася на фінансування транспортної галузі, 3 яких в середньому 94\% фінансувалася дорожнє господарство. Протягом 20102015 рр. друга за величиною частка видатків бюджету припадала на розвиток ПЕК - в середньому $35 \%$, проте у 2015 році склала лише 9,2\% у зв'язку із політико-економічною ситуацією в Україні та зміною державної стратегії. Третя за величиною частка видатків Державного бюджету України призначалася для допомоги сільському господарству - в середньому $16,18 \%$ за 5 років, проте у 2015 році частка зменшилася до 10,5\% від загальних витрат на економічну діяльність.

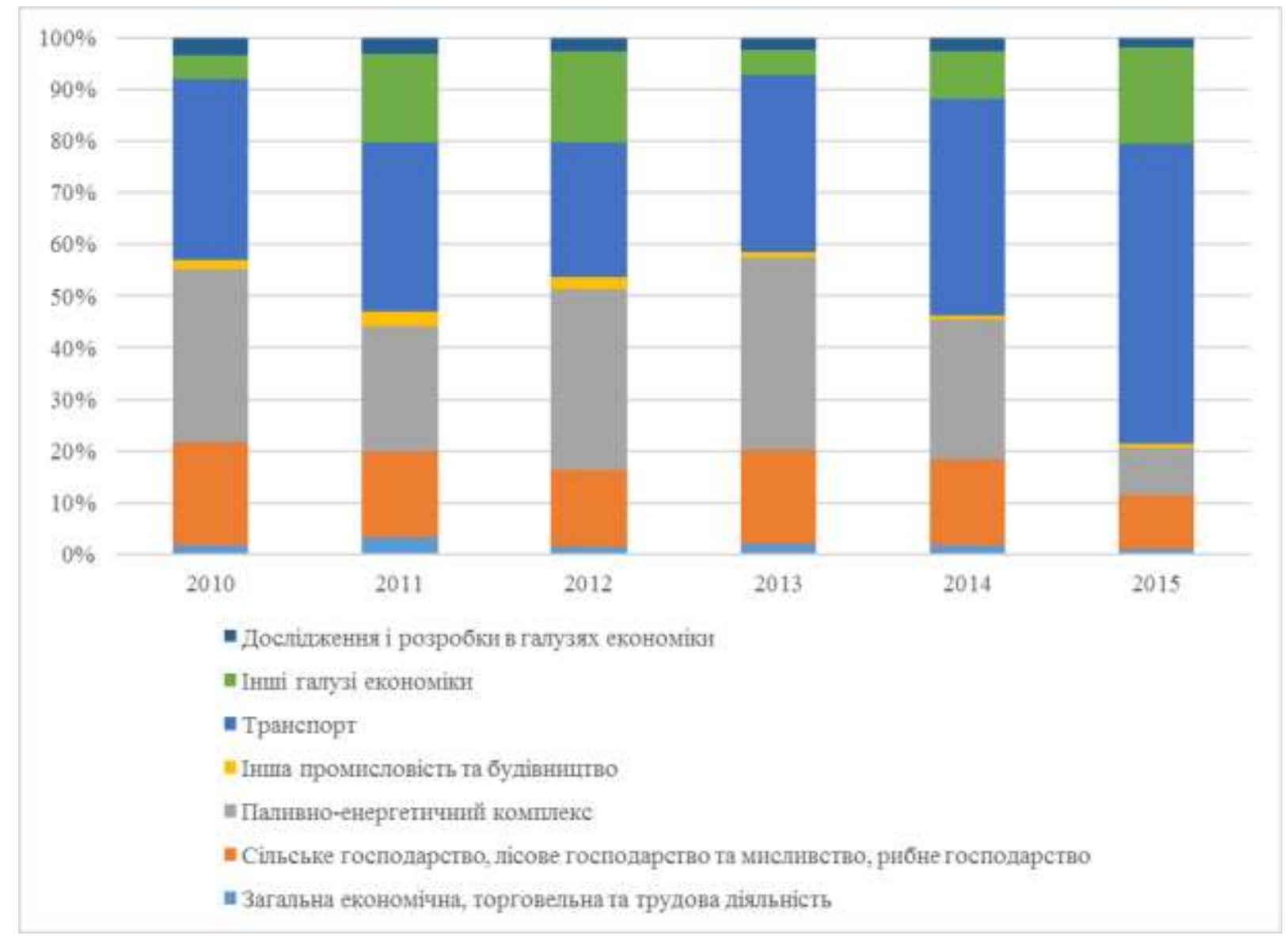

Рис. 2. Видатки Державного бюджету України за функціональною класифікацією видатків та кредитування бюджету

*2015 рік - планові видатки

Джерело: побудовано автором на основі [7]

У табл. 1 наведені вагові коефіцієнти складових економічної безпеки країни у порядку спадання на основі методичних рекомендацій щодо розрахунку рівня економічної безпеки України 2007 та 2013 років. 
Таблиця 1

Вагові коефіціснти субіндексів економічної безпеки за методиками 2007 та 2013 років

\begin{tabular}{|c|c|c|}
\hline \multirow[b]{2}{*}{$\Pi / \mathbf{H}$} & \multicolumn{2}{|c|}{ Методика 2007 року } \\
\hline & $\begin{array}{c}\text { Субіндекси } \\
\text { економічної } \\
\text { безпеки }\end{array}$ & $\begin{array}{c}\text { Ваговий } \\
\text { коефіціснт }\end{array}$ \\
\hline 1 & Енергетична & 0,1324 \\
\hline 2 & $\begin{array}{l}\text { Науково- } \\
\text { технологічна }\end{array}$ & 0,1183 \\
\hline 3 & Фінансова & 0,1127 \\
\hline 4 & Продовольча & 0,1108 \\
\hline 5 & Макроекономічна & 0,1005 \\
\hline 6 & Інвестиційна & 0,0939 \\
\hline 7 & $\begin{array}{l}\text { Зовнішньоекономі } \\
\text { чна }\end{array}$ & 0,0901 \\
\hline 8 & Демографічна & 0,0836 \\
\hline 9 & Соціальна & 0,0808 \\
\hline 10 & Виробнича & 0,0769 \\
\hline
\end{tabular}

\begin{tabular}{|c|l|c|}
\hline \multirow{2}{*}{ П/н } & \multicolumn{1}{|c|}{\begin{tabular}{c} 
Методика 2013 року \\
\cline { 2 - 3 }
\end{tabular}} & $\begin{array}{c}|c| \\
\text { безпеки економічної } \\
\text { Ваговий } \\
\text { коефіціснт }\end{array}$ \\
\hline 1 & Фінансова безпека & 0,1294 \\
\hline 2 & Макроекономічна безпека & 0,1224 \\
\hline 3 & Виробнича безпека & 0,1218 \\
\hline 4 & Енергетична безпека & 0,1148 \\
\hline 5 & $\begin{array}{l}\text { Зовнішньоекономічна } \\
\text { безпека }\end{array}$ & 0,1095 \\
\hline 6 & $\begin{array}{l}\text { Інвестиційно-інноваційна } \\
\text { безпека }\end{array}$ & 0,1089 \\
\hline 7 & Соціальна безпека & 0,1013 \\
\hline 8 & Продовольча безпека & 0,1007 \\
\hline 9 & Демографічна безпека & 0,0913 \\
\hline
\end{tabular}

Джерело: розроблено автором на основі [6,8,9]

Згідно 3 методикою 2007 року енергетична, науково-технологічна, фінансова та продовольча складові мали найбільший вплив на економічну безпеку України. У діючій методиці від 2013 року ваги суттєво змінилися: об'єднано науково технологічну та інвестиційну складові економічної безпеки в інвестиційно-інноваційну складову; енергетична, продовольча та інвестиційно-інноваційна складові займають тепер нижчі щаблі, ніж у методиці 2007 року. Зміна методики підрахунку пов'язана із світовою фінансовою кризою 2008 року: на перший план методики 2013 року вийшли фінансова, макроекономічна та виробнича складові.

Через події 2014-2015 років структура економіки України зазнала суттєвих змін: анексія українських територій, воєнні дії на Сході підірвали економічну безпеку країни. На думку автора, методика 2013 року вже $\epsilon$ застарілою. Під час військових дій на території України на перший план мають вийти енергетична, інвестиційно-інноваційна, продовольча, соціальна складові безпеки. На даний момент Україна не може повністю задовольнити потреби в паливно-енергетичних ресурсах та забезпечити захист національних інтересів у енергетичній сфері при зовнішніх та внутрішніх загрозах. Інвестиційно-інноваційна безпека України не здатна гарантувати державну незалежність за рахунок власних інновацій, бізнес-середовище не $\epsilon$ 
сприятливим для інвестицій тощо. Не менш важливим є моніторинг рівня продовольчої та соціальної безпеки під час воєнних дій в країні.

Видатки державного бюджету мають бути спрямовані на ті стратегічні види економічної діяльності, які забезпечать енергетичну, інвестиційноінноваційну, продовольчу, складові безпеки країни та матимуть найбільший соціально-економічний ефект.

Роль соціально-економічного ефекту при виборі стратегічних видів економічної діяльності для надання державної допомоги. Для аналізу соціально-економічного ефекту, яким характеризується різні види економічної діяльності, було обрано кількість зайнятих, частку ВВП та частку капітальних інвестицій у загальній сукупності. Кількість зайнятих працівників за видами економічної діяльності у 2014 році ілюструє рис. 3.

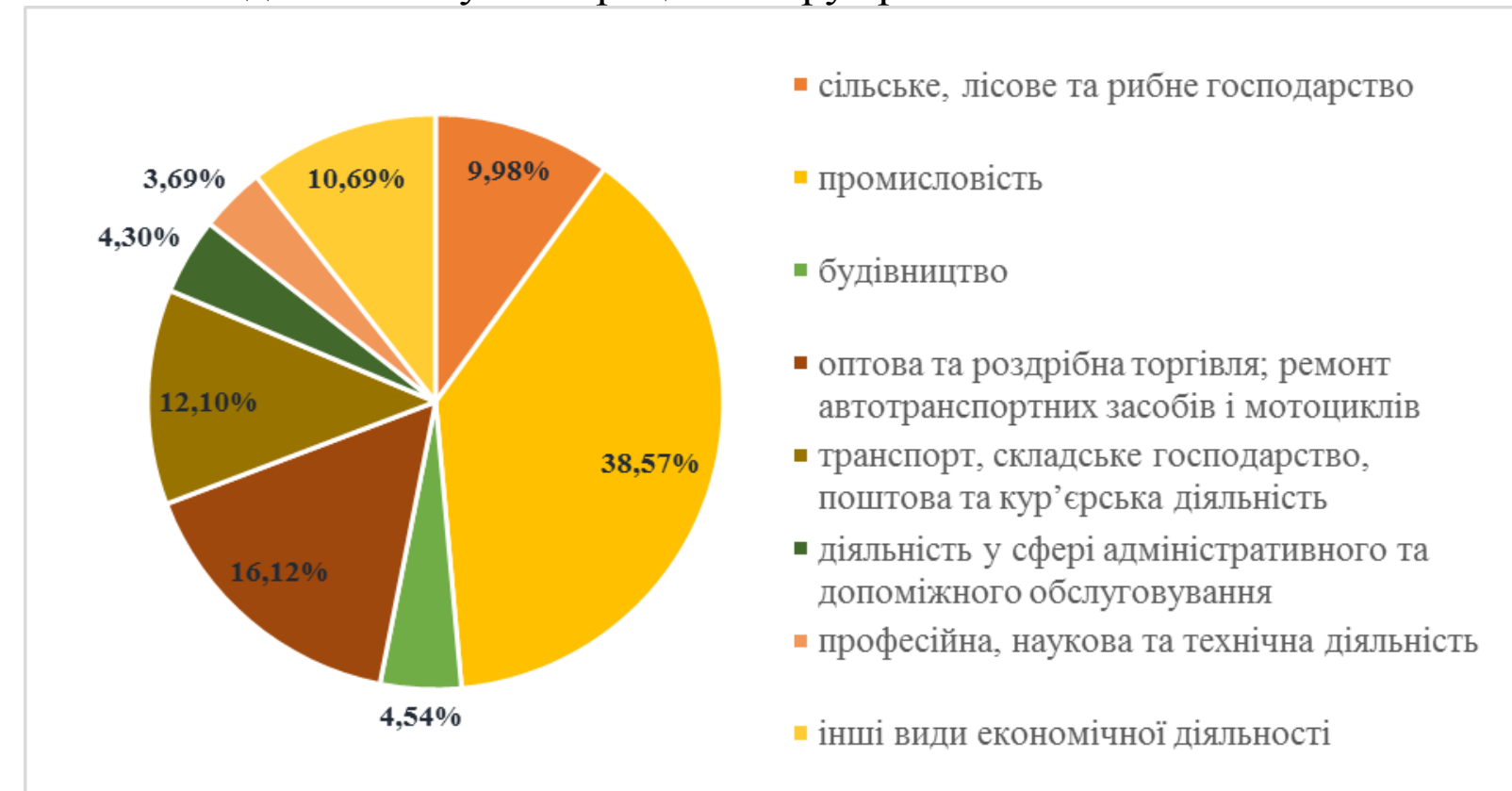

Рис. 3. Кількість зайнятих працівників за видами економічної діяльності у 2014 році (\% від загальної кількості)

Джерело: побудовано автором на основі [10]

Найбільша частка зайнятих спостерігається у промисловості - 38,57\%. Другу позицію щодо кількості зайнятих займає оптова та роздрібна торгівля $16,12 \%$. Третє місце належить транспортній галузі, яка характеризується $12,10 \%$ зайнятих від загальної кількості. У сільському господарстві частка зайнятих складає $9,98 \%$.

Рис. 4 показує динаміку кількості зайнятого населення за видами економічної діяльності, які мають найбільший відсоток, протягом 2010-2014 pp. 


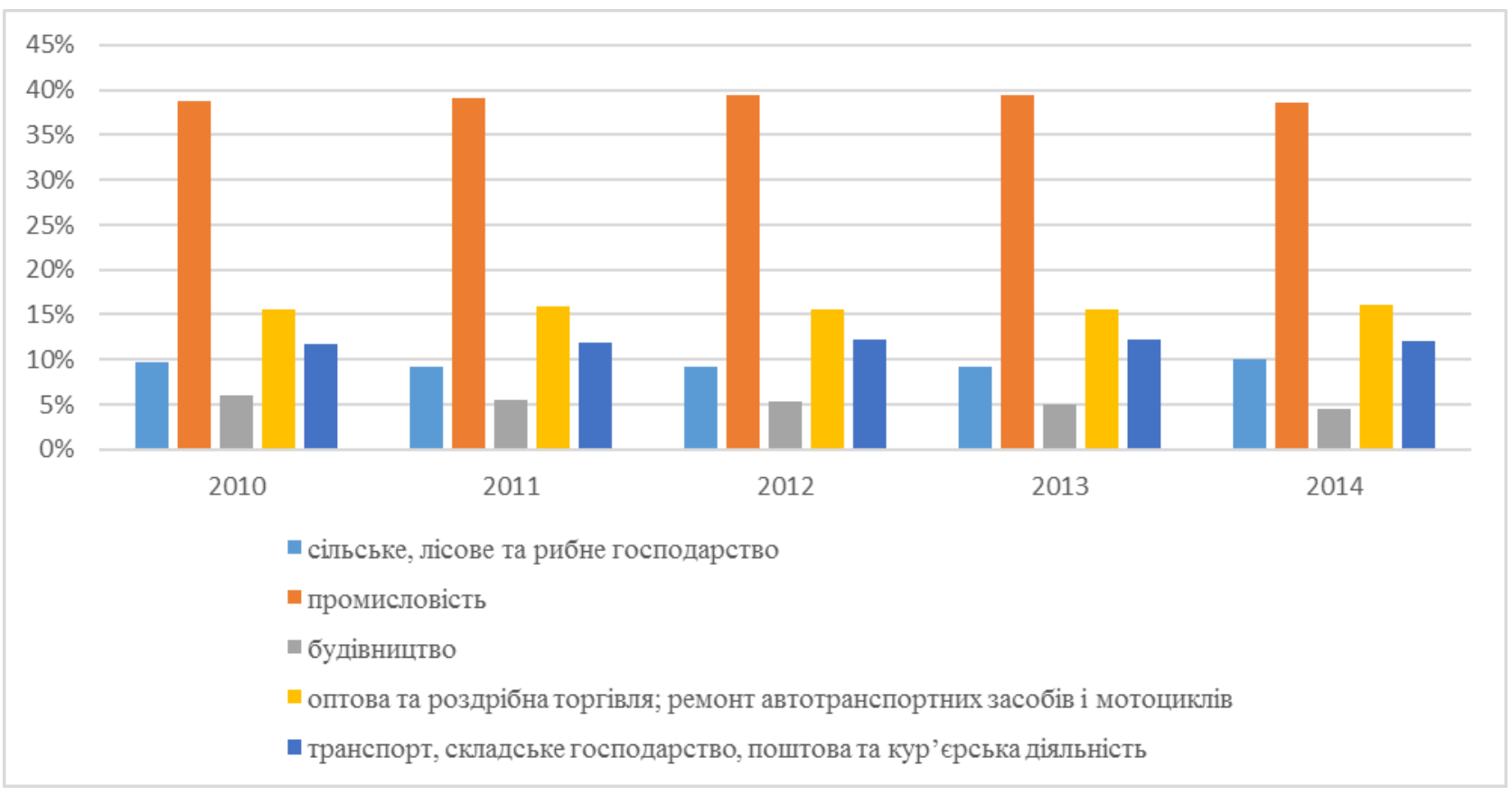

Рис. 4. Динаміка кількості зайнятих працівників за видами економічної діяльності 2010-2014 pp.

Джерело: побудовано автором на основі [10]

Проаналізувавши рис. 4, можна зробити висновок, що рейтинг видів економічної діяльності за кількістю зайнятих за 5 років не змінився.

3 метою дослідження економічного ефекту від видів економічної діяльності проаналізовано частки ВВП у загальній сукупності, які зображені на рис. 5.

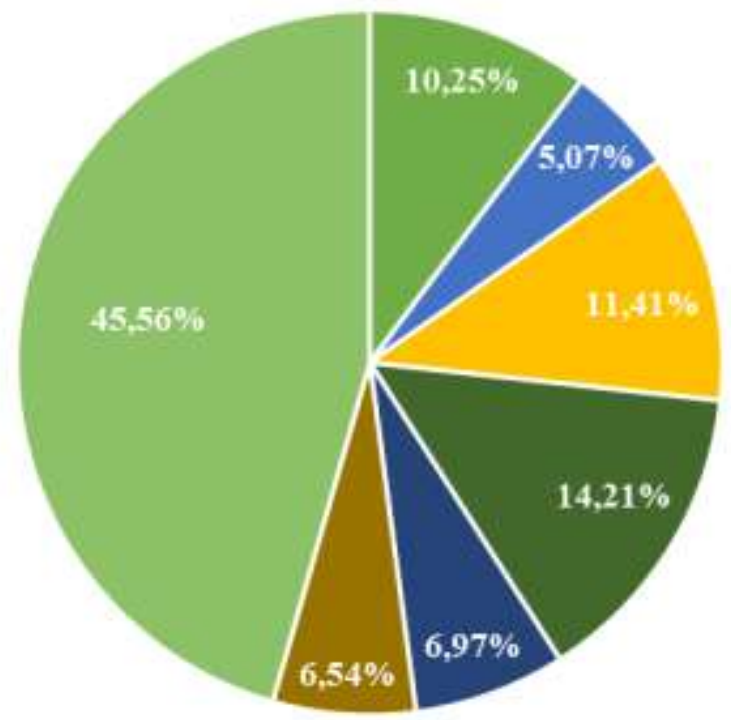

- Сільське, лісове тарибне господарство

- Добувна промисловість і розроблення кар'єрів

= Переробна промисловість

- Oптова та роздрібна торгівля, ремонт автотранспортних засобів і мотоциклів

- Транспорт, складське господарство, поштова та кур'єрська діяльність

- Oпераціїз нерухомим майном

- Інші види економічної діяльності

Рис. 5. Склад валового внутрішнього продукту у 2014 році 
Джерело: побудовано автором на основі [10]

Відповідно до Рис. 5, у 2014 році найбільший вклад у загальний ВВП мала оптова та роздрібна торгівля - 14,21\%. Переробна промисловість із часткою $11,41 \%$ займає другу позицію у рейтингу. Третє місце за вкладом у загальний ВВП займає сільське, лісове та рибне господарство з часткою 10,25\%. Частка транспортної галузі складає 6,97\%.

Рис.6 показує динаміку часток ВВП за видами економічної діяльності, які мають найбільший відсоток, протягом 2010-2014 pр.

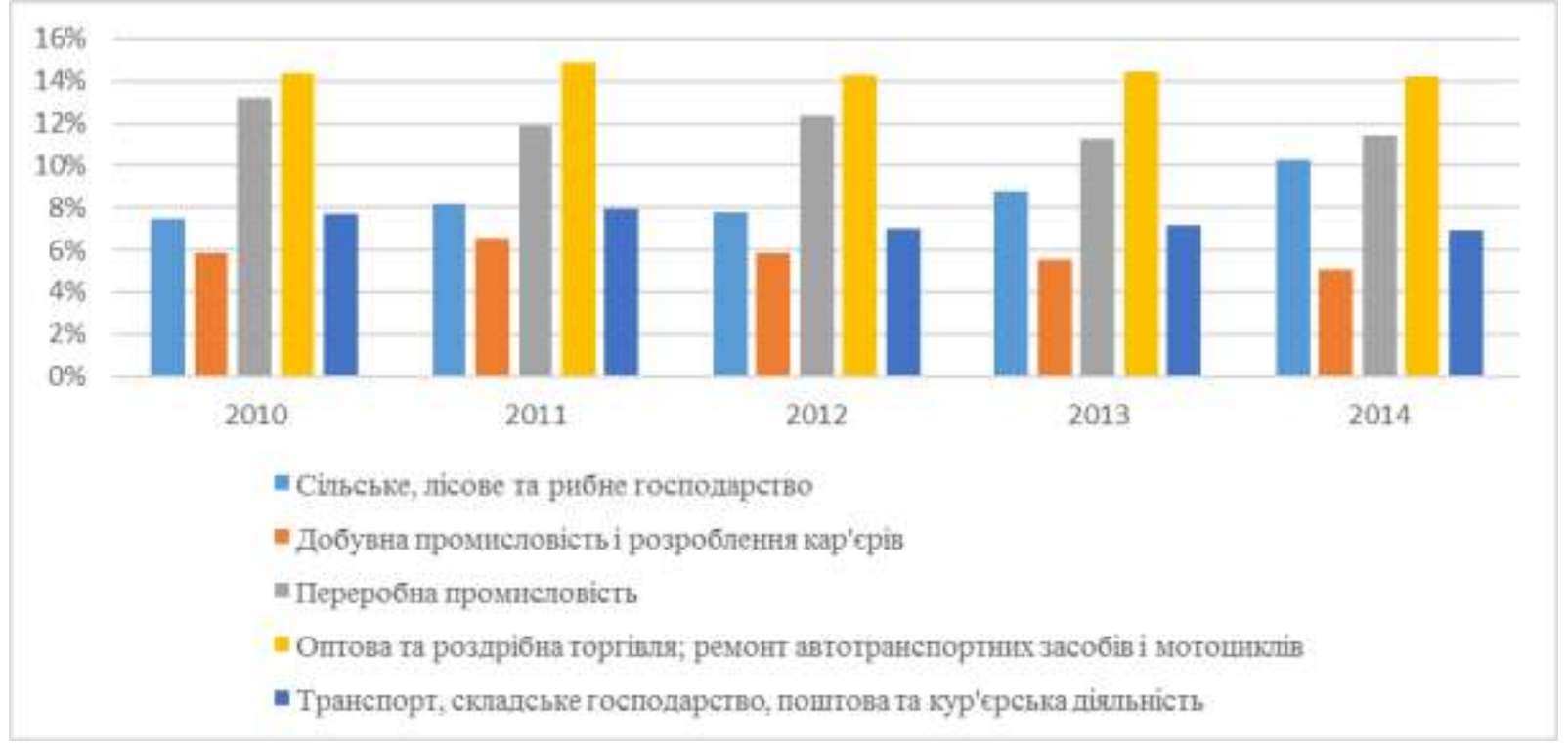

Рис. 6. Динаміка частки ВВП за видами економічної діяльності 20102014pp. Джерело: побудовано автором на основі [10]

Дослідивши динаміку часток ВВП за видами економічної діяльності 2010-2014 pp., робимо висновок, що вклад сільського господарства у ВВП зріс за 5 років $37,45 \%$ до $10,25 \%$, в той час як вклад транспортної галузі зменшився з 7,94\% у 2011 році до $6,97 \%$ у 2014 році.

3 метою аналізу найбільш привабливих для інвестицій видів економічної діяльності, у статті проаналізовано кількість капітальних інвестицій за видами економічної діяльності, які відображені на рис. 7. 


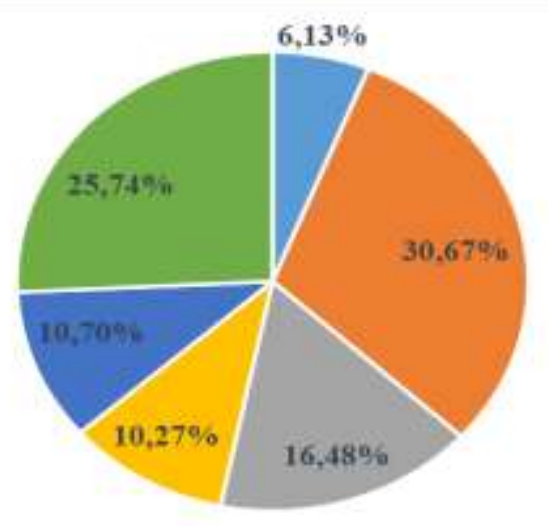

- Cinьcьке rocnoдарство, дісове rocnoдарство та рибне господарство

= Промнеловість

- Будівництво

- Oттова та ролдрібиа торгівля, ремонт автотранспортних засобів i мотошиклів

- Транспорт, складське господарство, поштова та кур'єрська діяльність

= Інші виддн скономічної діяльності

Рис. 7. Капітальні інвестиції за видами економічної діяльності у 2014 роки (\% від загальної кількості). Джерело: побудовано автором на основі [10]

Рис. 7 показує, що у 2014 році майже 40\% капітальних інвестицій направлено у Промисловість та $16,43 \%$ капітальних інвестицій - у Будівництво. Третє місце за кількістю вкладень належить Оптовій та роздрібній торгівлі $(9,44 \%)$, четверте місце - Сільському господарству $(8,57 \%)$ та п'яте місце - Транспорту $(7,06 \%)$.

Рис. 8 показує динаміку часток капітальних інвестицій за видами економічної діяльності, які мають найбільший відсоток, протягом 2010-2014 pp.

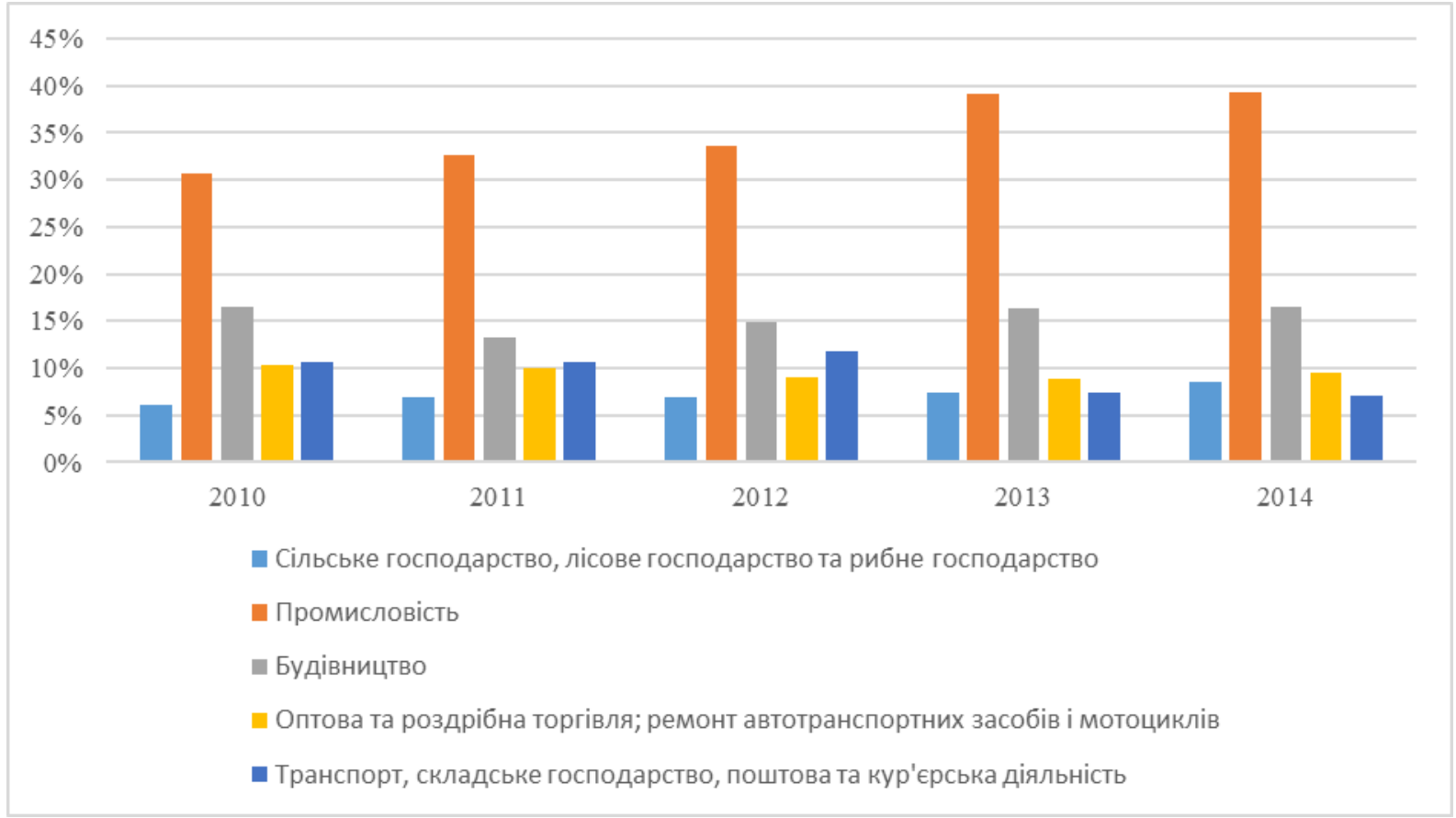

Рис. 8. Динаміка капітальних інвестицій за видами економічної діяльності 2010-2014 pp.

Джерело: побудовано автором на основі [10] 
Дослідивши рис.8, робимо висновок, що за 5 років частка капітальних інвестицій у промисловість зросла майже на $10 \%$, у сільське господарство більше ніж на $2 \%$, в той час як вкладення у Транспорт та Оптову та роздрібну торгівлю зменшилися близько $3 \%$ та $1 \%$ відповідно. Капітальні інвестиції у Будівництво зменшувалися протягом 2011-2012 рр., проте у 2014 році частка інвестицій знову досягла рівня 2010 року $-16,43 \%$.

Вибір видів економічної діяльності для надання державної допомоги. Дослідивши статистичні дані та провівши якісний аналіз отриманих результатів, проведено ранжування видів економічної діяльності за наступними критеріями, які мають відповідний ваговий коефіцієнт:

1. Роль в економічній безпеці (ЕБ) - 0,3.

2. Частка у ВВП - 0,15.

3. Частка зайнятих $-0,1$.

4. Частка видатків Державного бюджету (ДБ) - 0,3.

5. Частка капітальних інвестицій $-0,15$.

Вибір критеріїв та вагових коефіцієнтів відбувалися експертним шляхом. Найбільші вагові коефіцієнти надано критеріям «Ролі в економічній безпеці країні» та «Частці видатків Державного бюджету». По-перше, даний вибір пояснюється актуалізацією проблеми економічної безпеки Україні на міжнародній арені під час військових дій. Важливо надавати державну допомогу саме тим секторам економіки, які можуть закріпити позиції в безпеці нашої країни, що стане міцною базою для подальшого розвитку. Подруге, мета статті полягає у виборі секторів для надання державної допомоги, тому історичні дані видатків Державного бюджету мають велике значення при прийнятті рішення; даний критерій також має найбільший ваговий коефіцієнт.

Критерії «Частка ВВП» та «Частка капітальних інвестицій» $є$ другими за величиною вагових коефіцієнтів. Важливо надавати державну допомогу тим секторам, які забезпечують зростання ВВП та $\epsilon$ перспективними з точки зору інвесторів.

Державна допомога має бути спрямована у галузі, що забезпечують роботою велику частку економічно активного населення, тому «Частка зайнятих» також включено у критерії відбору стратегічних видів економічної діяльності, проте даний критерій характеризується найменшим ваговим коефіцієнтом.

У табл. 2 обрано види економічної діяльності, які мають найбільший влив за вищеописаними п'ятьма критеріями. Кожному сектору виставлено бали від 1 (найменший влив) до 4 (найбільший влив), обраховано загальну суму із врахуванням вагових коефіцієнтів кожного критерію. 
Таблиця 2

Вибір видів економічної діяльності для надання державної допомоги

\begin{tabular}{|c|c|c|c|c|c|c|}
\hline $\begin{array}{c}\text { Вид } \\
\text { економічної } \\
\text { діяльності / } \\
\text { Критерії } \\
\end{array}$ & $\begin{array}{c}\text { Роль } \\
\text { в ЕБ } \\
(0,3)\end{array}$ & $\begin{array}{c}\text { Частка } \\
\text { у ВВП } \\
(0,15)\end{array}$ & $\begin{array}{c}\text { Частка } \\
\text { зайнятих } \\
\quad(0,1)\end{array}$ & $\begin{array}{c}\text { Частка } \\
\text { видатків } \\
\text { ДБ } \\
(\mathbf{0 , 3 )} \\
\end{array}$ & $\begin{array}{c}\text { Частка } \\
\text { капітальних } \\
\text { інвестицій } \\
(0,15) \\
\end{array}$ & $\begin{array}{c}\text { Загальна } \\
\text { сума }\end{array}$ \\
\hline Транспорт & 1 & 1 & 2 & 4 & 1 & 1,85 \\
\hline $\begin{array}{c}\text { Сільське } \\
\text { господарство }\end{array}$ & 3 & 2 & 1 & 3 & 2 & 2,2 \\
\hline ПЕК & 4 & 3 & 3 & 2 & 4 & 2,55 \\
\hline $\begin{array}{c}\text { Оптова та } \\
\text { роздрібна } \\
\text { торгівля }\end{array}$ & 2 & 4 & 4 & 1 & 3 & 1,9 \\
\hline
\end{tabular}

Джерело: розроблено автором

В результаті отримано, що найбільш важливим для надання державної допомоги $є$ ПЕК та сільське господарство. Саме з цими секторами економіки України будуть проводитися наступні дослідження автора.

Висновки. В умовах гострого дефіциту державних коштів важливо правильно визначити пріоритетні напрями для стимулювання економічного розвитку. Економічна та політична ситуації в Україні швидко змінюються, тому виникає необхідність постійного моніторингу за наданням державної допомоги та іï результативності. Зношеність основних фондів, відсутність модернізації, незначні інвестиції, неконкурентноспроможність вітчизняних виробників свідчать про неефективність державної допомоги. Причиною цього є нецільове використання суб'єктами економічної діяльності отриманої державної допомоги, відсутність критеріїв відбору для надання державної допомоги та системи контролю над використанням наданих коштів.

В останні роки найбільша частка видатків виділялася на Транспорт, а саме на Дорожне господарство, тим не менш, рівень його розвитку залишається на низькому рівні, що свідчить про неефективність використання державних коштів. У статті проведено кількісний та якісний аналіз видів економічної діяльності за критеріями ролі в економічній безпеці країни та соціально-економічного ефекту. Підкреслено необхідність оновлення методики розрахунку рівня економічної безпеки України, яка в сучасних умовах не $\epsilon$ релевантною. Експертним шляхом обрано основні критерії при виборі стратегічних видів діяльності та їх вагових коефіцієнтів. На основі проведеного дослідження визначено, що Сільське господарство та ПЕК $\epsilon$ стратегічними видами економічної діяльності для надання державної допомоги. Наступні дослідження автора будуть базуватися на аналізі ефективності надання державної допомоги саме цим двом секторам економіки. 


\section{Література:}

1. Гендлер Г. Податкові пільги як фактор залучення інвестицій у розвиток депресивних територій / Г. Гендлер // Вісник державної податкової служби. - 2005. -№ 27. // http://www.visnuk.com.ua/?./journal/2705/274105.html

2. Звіт про результати дослідження державної підтримки суб'єктів господарювання в Україні. [Електронний ресурс] - Режим доступу: http://eupublicprocurement.org.ua/wpcontent/uploads/2015/04/STATE-SUPPORT-STUDY_UKR_20.04.2015.pdf

3. Затонацька Т. Г. Фіскальне регулювання інвестиційної діяльності в Україні: автореф. дис. ... д-ра екон. наук : 08.00.03 / Т. Г. Затонацька; Держ. навч.-наук. установа "Акад. фін. упр.". - К., 2013. - 35 с. - укр.

4. Скрипник А.В. Оцінка фіскальної ефективності пільгового оподаткування прибутку підприємств / Скрипник А.В., Серебрянський Д.М. // Економіка України - 2006. №7. - С. 13-27

5. Соколовська А. Податкові пільги в Україні: міфи та реальність / А. Соколовська // Вісник НБУ. - 2005. - № 9. - С. 7-12.

6. Методичні рекомендації щодо розрахунку рівня економічної безпеки України. Міністерства економіки України від 29.10.2013 № 1277. [Електронний ресурс] - Режим доступу: http://www.me.gov.ua/.

7. Офіційний веб-сайт Державної казначейської служби України [Електронний pecypc] Режим доступу: http://treasury.gov.ua/main/uk/doccatalog/list?currDir=14647

8. Методика розрахунку рівня економічної безпеки України. Наказ Міністерства економіки України від 02.03.2007 №60. [Електронний ресурс]- Режим доступу: http://www.me.gov.ua/ .

9. Таблиця основних показників економічного розвитку України. [Електронний pecypc] - Режим доступу: http://www.me.gov.ua/Documents/Detail?lang=ukUA\&id=085ab09c-ca24-4fee-ae13-

3cb51349507c\&title=OsnovniPokaznikiEkonomichnogoISotsialnogoRozvitkuUkraini

10. Офіційний веб-сайт Державного комітету статистики України. [Електронний pecypc] - Режим доступу: http://www.ukrstat.gov.ua/ 